\title{
Immunochemical Identification of a New Molecular Form of Acid Phosphatase of Host Origin Arising during Infection of Potato Tubers by Phytophthora erythroseptica Pethybr.
}

\author{
By J. A. LUCAS* AND D. PITT \\ Department of Biological Sciences, The University, Exeter, EX $44 Q G$
}

(Received I9 April 1974)

SUMMARY

Changes in multiple forms of acid phosphatase from potato tubers during infection by Phytophthora erythroseptica were detected by polyacrylamide gel electrophoresis. In recently lifted tubers these changes included the appearance of a new molecular form of low electrophoretic mobility. Seasonal studies established that a similar molecular form developed in healthy tubers during storage. An antiserum to acid phosphatase from potato tubers was shown to be specific for the host enzyme. Utilizing a sectional immunofocusing procedure the novel molecular form from infected tissues cross-reacted with the antiserum, suggesting that this component originated from the host.

\section{INTRODUCTION}

Protein changes in diseased plant tissues include alterations in multiple molecular forms of enzymes (Uritani, 197I). In few cases, however, is there direct evidence for the origin of these changes. The appearance of new molecular forms in the host-parasite complex may reflect a direct contribution by the pathogen or, alternatively, changes in the activity or synthesis of enzymes of the host (Sako \& Stahmann, 1972).

In a previous study Pitt (I970) provided evidence that multiple forms of enzymes capable of hydrolysing various naphthol esters are present in extracts of healthy potato tubers. After infection by the pink rot fungus Phytophthora erythroseptica Pethybr., new molecular forms of acid phosphatase and carboxylic esterase were detected in diseased tissue extracts. Of particular interest was the observation that some forms characteristic of healthy tissues apparently increased early in the infection process. The aim of the present study was to examine further the post-infectional changes in multiple forms of acid phosphatase and to investigate the origin of these changes by immunochemical means.

\section{METHODS}

Organism. The strain of $P$. erythroseptica was that used in an earlier investigation (Pitt \& Coombes, 1968).

Preparation of diseased tissues. Potato tubers cultivar Majestic were grown in the Botanical Garden, University of Exeter. Tubers were lifted in the first week of September and kept in a dark, frost-proof store. Inoculation with the pathogen was carried out through sterile incisions at the heel end and tubers were then incubated for 5 to 6 days at $25^{\circ} \mathrm{C}$, as

* Present address: Department of Plant Biology, University of Newcastle upon Tyne. 
described by Pitt \& Coombes (1968). After this time disease lesions extended through approximately half of the tuber. The pink coloration associated with the lesion made it possible to isolate precisely samples from uninfected tissue, the newly infected area at the leading edge of the lesion and the necrotic zone. These samples were designated $\mathbf{H}$ (healthy), Fr (disease front) and WR (whole rot). The healthy (H) samples were generally obtained from uninoculated control tubers, since protein changes might occur in apparently healthy tissues well in advance of the disease lesion. In each experiment tissue from at least three healthy and three infected tubers was separately combined to make up each sample.

Extraction of proteins. Tissue samples (approx. I $\mathrm{g}$ fresh tissue $/ \mathrm{ml}$ buffer) were homogenized in a 'Vortex' tissue homogenizer (Measuring and Scientific Equipment Ltd) operating at $\mathrm{I} 2000 \mathrm{rev}$. $/ \mathrm{min}$ for 2 to $3 \mathrm{~min}$ at $0^{\circ} \mathrm{C}$ in $0 . \mathrm{I} \mathrm{M}$-tris- $\mathrm{HCl}$ buffer $\mathrm{pH} 8.0$ in $0.5 \mathrm{M}$-sucrose containing ascorbic acid and cysteine hydrochloride at $0 . \mathrm{I} \%(\mathrm{w} / \mathrm{v})$. Homogenates were strained through two layers of muslin, centrifuged for $10 \mathrm{~min}$ at $3000 \mathrm{~g}$ at $0{ }^{\circ} \mathrm{C}$ to remove larger cell debris, and then recentrifuged for $30 \mathrm{~min}$ at $23000 \mathrm{~g}$ to give a clear extract which was stored in small amounts at $-20^{\circ} \mathrm{C}$ under nitrogen.

Mycelial extracts and culture filtrates of $P$. erythroseptica were prepared by growing the fungus in shake culture on potato dextrose broth for I week at $25{ }^{\circ} \mathrm{C}$. Mycelial pellets were harvested by filtration and homogenized in reducing buffer, as described for tuber tissue samples. Alternatively, the fungus was grown in the presence of host cells by inoculation of small blocks of agar culture into a suspension culture of potato callus cells obtained and maintained by the methods of Ingram \& Robertson (1965). After 5 to 7 days' growth at $25{ }^{\circ} \mathrm{C}$ fungus pellets were removed, washed free of contaminating callus cells, and homogenized. Mycelial extracts and culture filtrates were stored at $-20^{\circ} \mathrm{C}$ under nitrogen.

Assay procedures. (i) Acid phosphatase (EC. 3.1.3.2) activity of tissue extracts was determined by using $p$-nitrophenyl phosphate as the substrate, as described by Pitt $\&$ Galpin (197I), with the liberated nitrophenol being read spectrophotometrically at $400 \mathrm{~nm}$. Appropriate zero-time blanks and controls incorporating $0.0 \mathrm{I}$ M-sodium fluoride were carried out. A unit of enzyme activity was that amount of enzyme liberating I $\mu \mathrm{mol} p$-nitrophenol/ min under the conditions of the assay. (ii) Soluble proteins in tissue extracts were determined by the method of Lowry, Rosebrough, Farr \& Randall (I95I).

Polyacrylamide-gel electrophoresis. A Shandon disc electrophoresis apparatus was used according to the procedures of Ornstein (1964) and Davis (1964). The gel system had a $\mathrm{pH}$ of 8.5 , with the small pore gel containing $7.5 \%(\mathrm{w} / \mathrm{v})$ acrylamide and the large pore gel $2.5 \%$ (w/v) acrylamide with appropriate amounts of $N, N^{\prime}$-methylene bis acrylamide. Polymerization of the small pore gel was achieved with ammonium persulphate and $N, N, N^{\prime}, N^{\prime}$-tetra methyl ethylene diamine (TEMED). The large pore gel was polymerized with riboflavin for I 5 min using a fluorescent light. The reservoir buffer consisted of glycine $(2 \cdot 88 \mathrm{~g} / \mathrm{l})$ and tris $(0.6 \mathrm{~g} / \mathrm{l})$ and was discarded after use. Enzyme preparations, containing $200 \mu \mathrm{g}$ soluble protein, were applied by micropipette, and the gels run at $4{ }^{\circ} \mathrm{C}$ with a current of $2 \mathrm{~mA} /$ tube for $30 \mathrm{~min}$, followed by $35 \mathrm{~min}$ at $3 \mathrm{~mA} /$ tube. Gels were removed from tubes by hypodermic irrigation and washed in cold distilled water before staining.

Acid phosphatase was demonstrated by the method of Pitt (1970). Control gels incubated in media containing 0.01 M-sodium fluoride or media from which substrate or dye had been omitted demonstrated that the procedure was specific for acid phosphatase.

Densitometry of gels. Densitometer traces of gels were obtained as described by Pitt (1970), by using a Leitz Ortholux microscope with a motorized stage drive and a Leitz MPV photometer, suitably modified and coupled to a chart recorder. This method was found to give better resolution of enzyme bands than scanning with a commercial densito- 
meter. Enzyme bands were numbered according to the recommendations of the IUPACIUB Commission on Biochemical Nomenclature (1972), with individual bands being distinguished and numbered on the basis of electrophoretic mobility, the number I being assigned to that form having the highest mobility towards the anode.

Preparation of antiserum. A commercial enzyme preparation was used (Boehringer, Mannheim, acid phosphatase grade $\mathrm{I}$ from potatoes). Electrophoresis of this preparation on polyacrylamide gel gave similar profiles to acid phosphatase from crude tuber homogenates (Lucas, 1973), and was therefore considered suitable for use as an enzyme antigen. The bovine serum albumin included in the commercial preparation as a stabilizing agent was removed by low-speed centrifugation in $3 \cdot 2 \mathrm{M}$-ammonium sulphate solution to sediment the enzyme, which was then resuspended and washed (twice) in fresh $3.2 \mathrm{M}$-ammonium sulphate solution. The enzyme was then taken up in $0.85 \%(\mathrm{w} / \mathrm{v})$ saline, mixed with the appropriate amount of Freund's complete adjuvant, and sterilized by passage through a Millipore filter $(0.22 \mu \mathrm{m}$ pore size).

Rabbits (New Zealand Whites, Lop Ear Hybrids) weighing approximately $2 \mathrm{~kg}$ were injected subcutaneously at weekly intervals over I month. The first and second injections contained $0.5 \mathrm{mg}$ enzyme protein in $0.7 \mathrm{ml}$ saline $(0.85 \%, \mathrm{w} / \mathrm{v}, \mathrm{NaCl})$ plus $0.25 \mathrm{ml}$ Freund's complete adjuvant. The third injection contained I mg enzyme protein in $0.8 \mathrm{ml}$ saline plus $0.1 \mathrm{ml}$ adjuvant. The final injection contained $\mathrm{I} .5 \mathrm{mg}$ enzyme protein in $0.8 \mathrm{ml}$ saline plus $0.1 \mathrm{ml}$ adjuvant. Two weeks after the final injection the animals were bled from the ear. Serum was stored in small portions in polystyrene vials at $-20^{\circ} \mathrm{C}$.

To increase antibody titre and serum yield a booster injection was administered 6 weeks after the initial immunization series. This contained I mg enzyme protein in $0.4 \mathrm{ml}$ saline with $0.1 \mathrm{ml}$ adjuvant. After I week a trial bleed was carried out and the rabbit was then exsanguinated.

Control serum was obtained by carrying out a similar immunization series with saline and adjuvant, but excluding enzyme antigen.

Double immunodiffusion technique. The immunodiffusion technique of Ouchterlony (1953) was done in Petri dishes containing I \% (w/v) Ionagar (Oxoid) in $0.425 \%$ saline with $0.1 \%$ (w/v) sodium azide as preservative.

Immunoelectrophoresis. This was done on agar-covered slides by the method of Graber \& Williams (1955) in a commercial apparatus (Shandon Scientific Co. Ltd) using Owen's quarter-strength buffer. Runs lasted $\mathrm{I} \cdot 5 \mathrm{~h}$ at $30 \mathrm{~mA}$ with development for $36 \mathrm{~h}$ in the presence of antiserum and subsequent staining for $3 \mathrm{~h}$ in $0.2 \%(\mathrm{w} / \mathrm{v})$ Ponceau $\mathrm{S}$ in $5 \%(\mathrm{w} / \mathrm{v})$ trichloroacetic acid.

During investigations on the immunological specificity of the acid phosphatase antisera a rabbit anti-bovine serum albumin serum was used (Hoechst Pharmaceuticals; anti-BSA serum). Bovine albumin (Armour Pharmaceutical Ltd, Eastbourne), $20 \%$ (w/v), was used as the antigen in cross-reaction studies.

Inhibition of enzyme activity by specific antibody. Solutions of a commercial enzyme (Boehringer, acid phosphatase grade II, lyophilized, from potato tubers, at a concentration of $0.5 \mathrm{mg} / \mathrm{ml}$ ) and crude tuber homogenates were incubated for $30 \mathrm{~min}$ with an equal volume of acid phosphatase antiserum. Reaction mixtures were then centrifuged for 15 min at $100 \mathrm{~g}$ to remove precipitin complexes, and acid phosphatase activity in the supernatant fractions determined as described previously. Control samples were incubated with Freund control antiserum before enzyme assay. 


\section{RESULTS}

\section{Electrophoresis of tuber extracts}

Results of initial experiments on the electrophoretic patterns of acid phosphatase in extracts of healthy and disease-front zones in recently lifted tubers cultivar Majestic were in substantial agreement with the findings of Pitt (1970) (Fig. I). Healthy samples contained two enzyme bands with the major activity at position 2 . Infected samples showed the same bands plus a dense new band of low electrophoretic mobility (position 5). There was also evidence for the appearance of another new band (position 3) and an increase in the activity of one of the components characteristic of healthy tissue (position I). However, while the apparently novel enzyme bands appeared in infected tissues, traces of activity in similar positions could also be detected in healthy controls.

Subsequent experiments using tubers that had been stored at $10^{\circ} \mathrm{C}$ for 2 or 3 months before infection indicated that the same additional enzyme bands appeared in healthy tissues during storage. In order to clarify these changes and the possible influence of infection on the acid phosphatases, samples were obtained at periodic intervals throughout the following season, and their electrophoretic patterns determined. Representative gels are shown in Fig. 2. In early-season samples a major new band was located at position 5 in infectedtissue extracts. However, by November a similar band appeared in healthy samples, and this band was apparent in all subsequent samples taken throughout the season. Other sequential changes were also observed, including a gradual increase in the density of the major acid phosphatase component (position 2), and the appearance of a minor band at position 3 . These results suggested that the presence of the prominent new enzyme band in early-season nfected samples might reflect a premature induction or activation of a molecular form characteristically appearing later in the season in healthy tubers.

\section{Electrophoresis of mycelial extracts and culture filtrates}

When $P$. erythroseptica was grown in potato dextrose broth or suspension callus culture, identical patterns of acid phosphatase were obtained by electrophoresis of mycelium homogenates. Two main bands were detected, with the major activity of low electrophoretic mobility coinciding in position with the new enzyme band observed in extracts from infected potato tissue (Fig. 3). Culture filtrates from the above cultures contained traces of the two bands detected in mycelial extracts. There was no evidence for the appearance of new molecular forms when the fungus was grown in the presence of host cells.

\section{Immunological specificity tests}

When purified acid phosphatase from potato tubers was tested by double immunodiffusion in agar with its corresponding antiserum, a single precipitin arc between enzyme antigen and antiserum was detected down to $\mathrm{I}: \mathrm{I} 6$ dilution of antiserum. A second batch of antiserum obtained after a booster injection administered 6 weeks after the initial immunization series gave a higher antibody titre but yielded two precipitin arcs with the original enzyme antigen. As the original enzyme antigen was supplied as a suspension in bovine serum albumin (BSA), it was suspected that this second precipitin arc was due to antibody formed in response to residual BSA present in the fractionated enzyme. This was confirmed by immunoelectrophoretic investigation using an antiserum specific for BSA. Crude tuber homogenates, however, gave no cross-reaction with the anti-BSA serum, and 


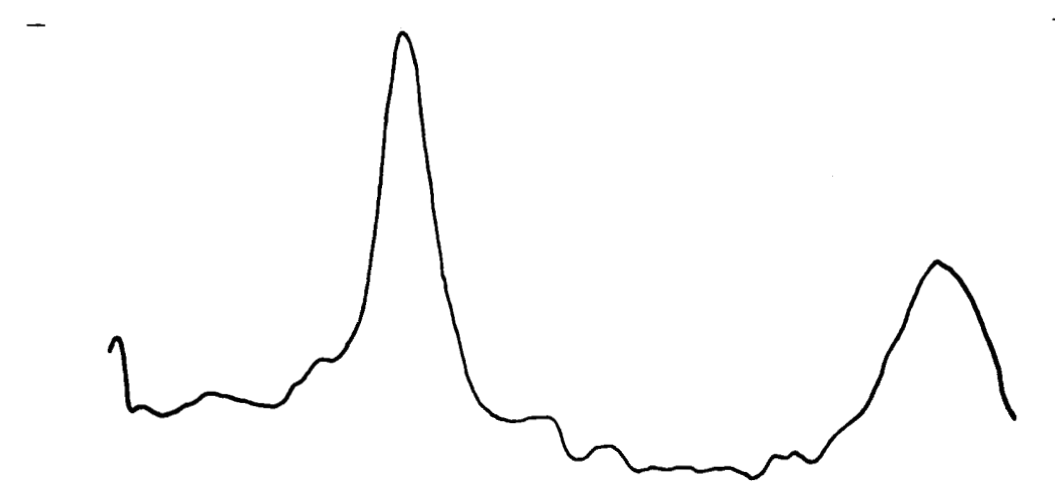

H
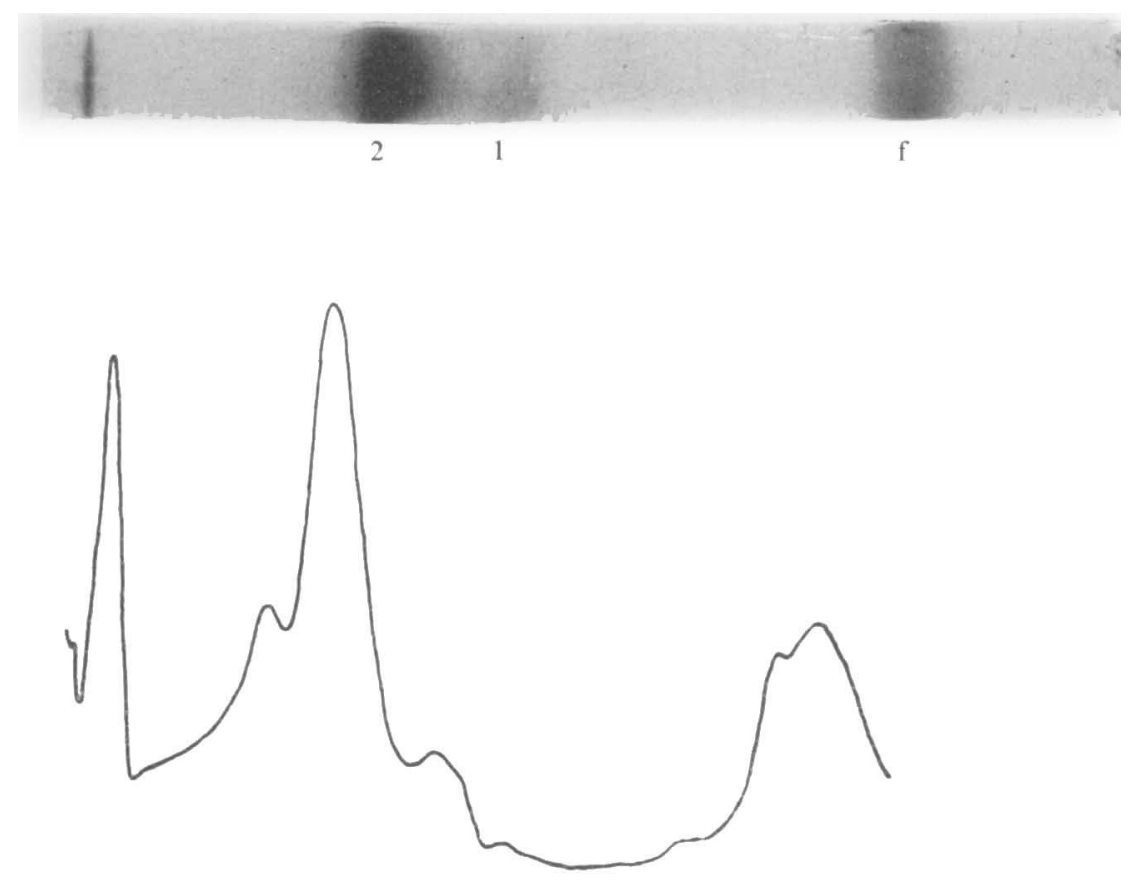

Fr

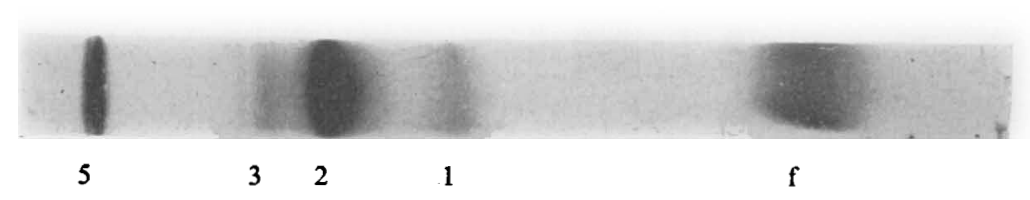

Fig. I. Electrophoretic patterns of acid phosphatase in healthy $(\mathrm{H})$ and disease front $(\mathrm{Fr})$ zones of tubers cultivar Majestic infected by $\boldsymbol{P}$. erythroseptica. f, Electrophoretic front. 
-

H

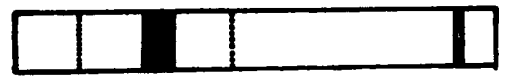

Oct.

Fr

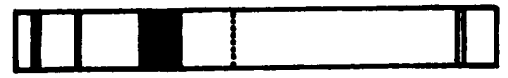

H

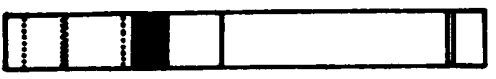

Fr

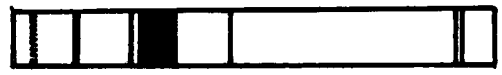

Nov.

H

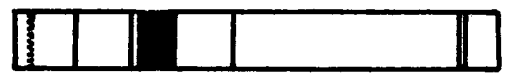

Dec.

Fr

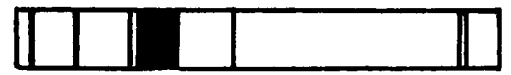

H

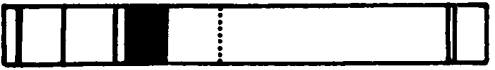

Jan.

Fr

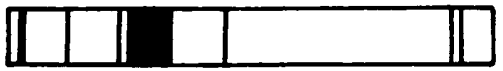

H

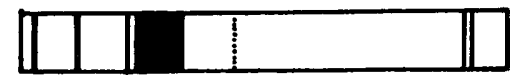

Fr

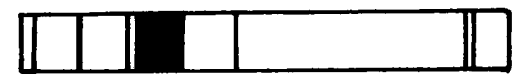

Feb.

H

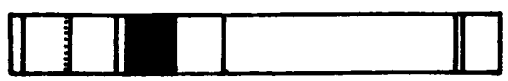

Mar.

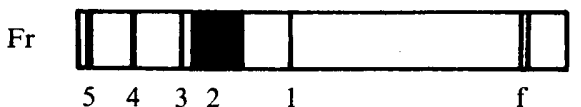

Fig. 2. Electrophoretic patterns of acid phosphatase in healthy $(\mathrm{H})$ and disease front $(\mathrm{Fr})$ zones of tubers cultivar Majestic infected by $P$. erythroseptica. Samples obtained at monthly intervals from October until March.

precipitin arcs obtained by this method coincided exactly with cross-reactions between purified enzyme and anti-phosphatase serum (Lucas, 1973).

The cross-reactivity of the anti-phosphatase serum with samples of potato tuber, leaf and callus homogenates, and mycelial extracts of $\boldsymbol{P}$. erythroseptica was investigated by the double-immunodiffusion technique in agar gel. No precipitin arcs were observed, except in 

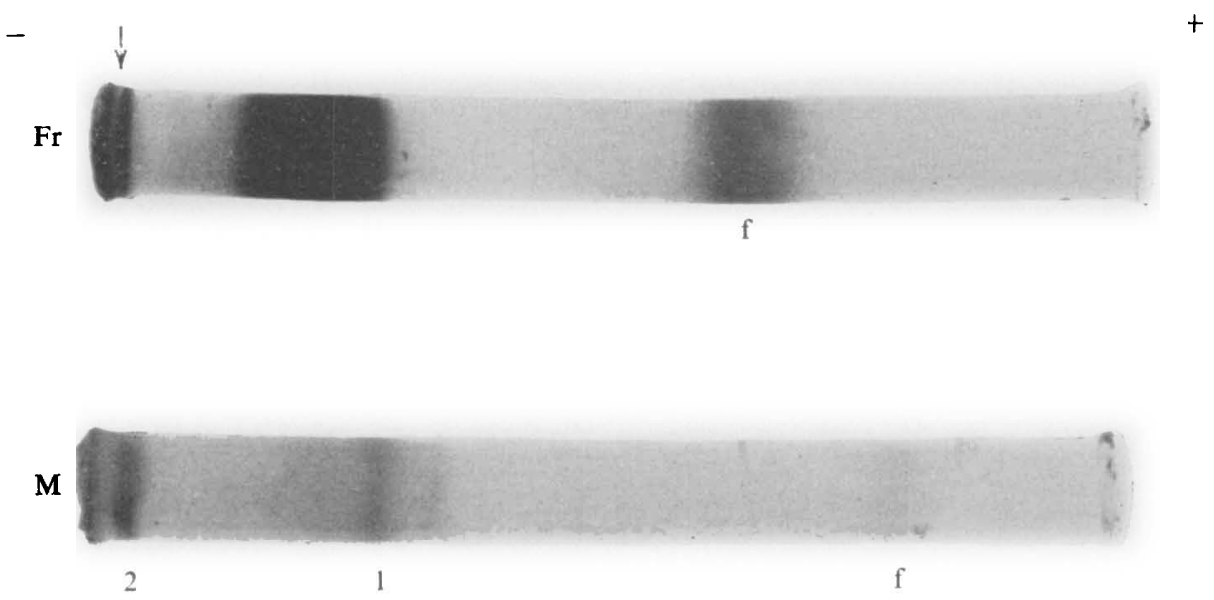

Fig. 3.'Electrophoretic patterns of acid phosphatase in the disease front (Fr) zone of tuber cultivar Majestic infected by $P$. erythroseptica, and in a mycelial extract $(M)$ of the fungus grown in the presence of potato callus cells. Arrow indicates post-infectional enzyme band.

Table I. Inhibition of acid phosphatase activity by specific antiserum

$\begin{array}{lccc}\text { Sample } & \begin{array}{c}\text { Specific activity } \\ \text { serum }\end{array} & \begin{array}{c}\text { +Anti- } \\ \text { phosphatase } \\ \text { serum }\end{array} & \begin{array}{c}\text { Change in } \\ \text { activity } \\ (\% \text { control })\end{array} \\ \text { Commercial enzyme } & 0.74 & 0.35 & -53.4 \\ \text { Tuber homogenate } & 0.65 & 0.34 & -47 \cdot 1\end{array}$

the case of potato tuber samples, which gave a single line within $24 \mathrm{~h}$. Control antisera did not cross-react with any of the tissue extracts.

Treatment of a solution of a commercial acid phosphatase preparation from tubers, and crude tuber homogenates, with anti-phosphatase serum before enzyme assay led to a reduction of about $50 \%$ in the activity of both samples, compared with values obtained for identical samples pre-incubated with control serum (Table $\mathrm{I}$ ).

On the basis of these specificity tests it was concluded that the serum contained antibody specific towards acid phosphatase obtained from potato tubers.

\section{Sectional immunofocusing}

Enzyme bands in healthy and infected tuber extracts were cross-reacted with the antiphosphatase serum by using a modification of the method described by Catsimpoolas (1969). Samples were separated by polyacrylamide gel electrophoresis and stained for acid phosphatase activity as previously described. Identical unstained gels were sectioned at points equivalent to the stained enzyme bands and the gel sections were then extruded through a syringe into wells cut in agar plates ( $\mathrm{I} \%, \mathrm{w} / \mathrm{v}$, Ionagar No. 2 in barbitone-acetate buffer $\mathrm{pH}$ 8.6). Elution of antigen from macerated gel sections was aided by addition to the wells of a small volume of barbitone-acetate buffer. Anti-phosphatase serum was placed in wells opposite the gel samples. The plates were then left for $24 \mathrm{~h}$ at room temperature. 


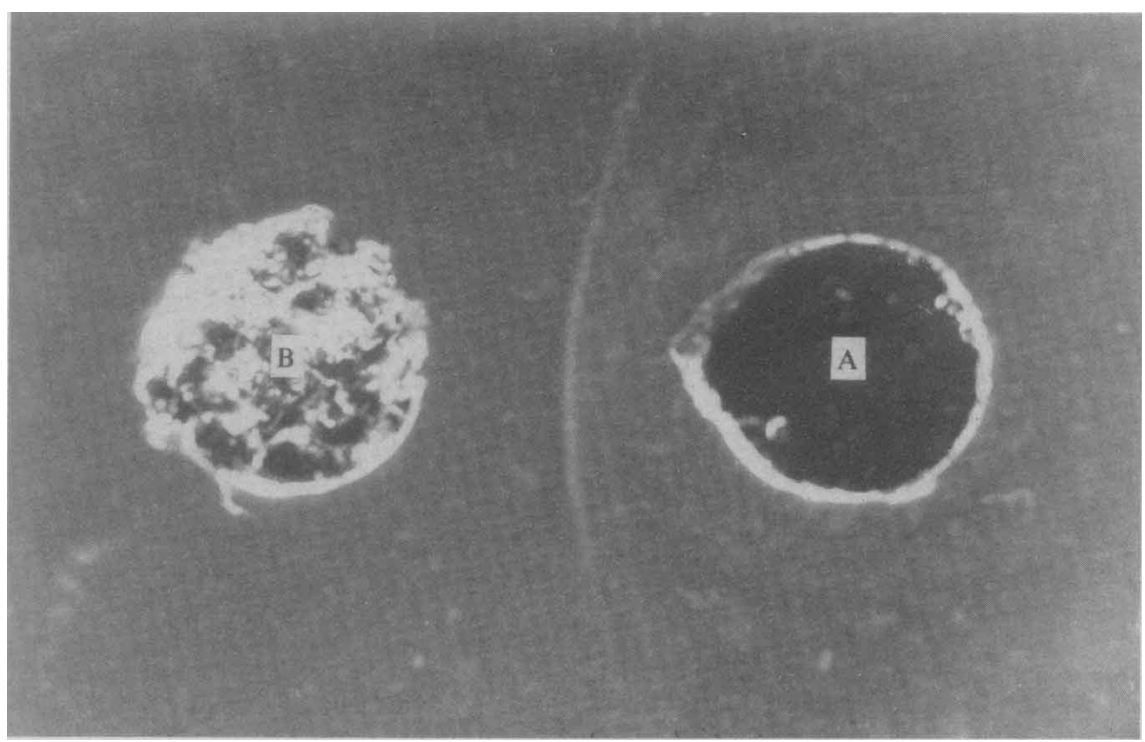

Fig. 4. Detail of immunodiffusion plate showing cross-reaction of anti-phosphatase serum (well A) with a post-infectional enzyme band eluted from macerated gel sections (well B).

Acrylamide gel sections containing the major acid phosphatase band at position 2 from both healthy and infected samples showed a single precipitin arc in each case. In some instances, however, traces of a second precipitin arc were detected, suggesting that the major molecular form from tubers might in fact comprise two antigenically distinct components. In infected samples, gel sections equivalent to the new enzyme band at position 5 also gave a positive result with anti-phosphatase serum, yielding a single precipitin arc in all cases (Fig. 4).

\section{DISCUSSION}

Infection of potato tubers by $P$. erythroseptica involves complex changes in acid hydrolases, including the liberation of preformed enzymes from host-cell lysosomes (Pitt \& Coombes, I968, I969) and sequential alterations in multiple molecular forms (Pitt, 1970). Qualitative and quantitative post-infectional changes in molecular forms of acid hydrolases have been reported from other host-pathogen combinations. Staples \& Stahmann (I964) resolved two new acid phosphatase isoenzymes in extracts of bean leaves infected by Uromyces phaseoli, although total acid phosphatase activity was reduced. On the basis of electrophoretic mobility, heat stability and pH optima, Williams \& Staples (I964) concluded that a new form of acid phosphatase present in rusted bean leaves originated from the fungus. Using similar criteria Rudolph \& Stahmann (1966) proposed that a new isoenzyme of acid phosphatase appearing in bean leaves infected by Pseudomonas phaseolicola was of bacterial origin, although these authors also obtained evidence for an increase in the major acid phosphatase component from leaves following infection.

While isoenzyme changes in infected plant tissues are well documented, clear evidence for the origin and significance of these changes is lacking in most cases. Sako \& Stahmann (1972) considered that alterations in multiple molecular forms of enzymes may represent biochemical symptoms of disease, and concluded that by no means all of the alterations can be explained by a simple contribution from the pathogen. It seems possible, therefore, that 
the pathogen may exert some control over the activity or synthesis of host enzymes. The high specificity of antigen-antibody reactions offers a means of precisely identifying proteins in the host-parasite complex, but has not been widely utilized in plant pathology. Heitefuss, Buchanan-Davidson, Stahmann \& Walker (1960) used electrophoresis and immunochemical procedures to analyse protein extracts from cabbage seedlings infected by Fusarium oxysporum $\mathrm{f}$. conglutinans and detected the occurrence of three new antigenic components specific to diseased tissues. More recently, Cheung \& Willetts (1973) used serological techniques and enzyme-staining methods to investigate changes in isoenzymes from wheat leaves infected by stem rust. In both these studies, however, antisera were prepared against heterogeneous protein extracts from the host or the fungus, rather than a single purified protein.

The pattern of seasonal changes in multiple forms of acid phosphatase from healthy tubers, along with the cross-reaction of the new post-infectional enzyme band with specific antiserum, would seem to provide good evidence for a host origin of this component. It does not, however, preclude the possibility that the fungus may make some contribution to the new band. The low level of production of acid phosphatase by $P$. erythroseptica, even when grown in the presence of potato callus cells, suggests that the pathogen may not necessarily be a significant source of enzyme. Alterations in molecular forms of acid phosphatase during the senescence of plant tissues have been reported by other authors (De Leo \& Sacher, 1970; Baker \& Takeo, 1973) and the premature appearance in infected tuber tissues of an enzyme band characteristically found in older tubers might represent an accelerated ageing of host cells induced by the fungus.

The observation that gel sections containing the major acid phosphatase component from tubers sometimes yielded two precipitin arcs with the antiserum, indicated that although this component appeared to be homogeneous on the basis of electrophoretic mobility, antigenically it may have comprised more than one molecular form. Kubicz (1973) has provided evidence that the major form of acid phosphatase from potato tubers is composed of two similar or nearly identical subunits. Although it is not yet clear whether the two precipitin arcs represented cross-reactions with separate enzyme subunits, the result emphasizes the need for caution in interpreting electrophoretic evidence, and, in particular, defining isoenzymes on an operational basis.

One of us (J.A.L.) thanks the S.R.C. for financial support during this investigation.

\section{REFERENCES}

BAKer, J. E. \& TAKeo, T. (1973). Acid phosphatase in plant tissues. I. Changes in activity and multiple forms in tea leaves and tomato fruit during maturation and senescence. Plant and Cell Physiology 14, 459-471.

Catsimpoolas, N. (1969). Immunoelectrofocusing. Science Tools $16,1-5$.

Cheung, D. S. M. \& Willetts, H. J. (1973). Changes in proteins and isoenzymes in leaves of wheat infected by stem rust. Archives of Microbiology 91, 365-372.

Davis, B. J. (1964). Disc electrophoresis. II. Method and application to human serum proteins. Annals of the New York Academy of Sciences 121, 404-427.

De Leo, P. \& SACHer, J. A. (1970). Senescence. Association of acid phosphatase with banana ripening. Plant Physiology 46, 208-211.

Graber, P. \& Williams, C. A., Jun. (1955). Méthode immunoélectrophoretique d'analyse des mélanges de substances antigéniques. Biochimica et biophysica acta 14, 67-74.

Hertefuss, R., Buchanan-Davidson, D. J., Stahmann, M. A. \& Walker, J. C. (1960). Electrophoretic and immunochemical studies of proteins in cabbage infected with Fusarium oxysporum $\mathrm{f}$. conglutinans. Phytopathology 50, 198-205. 
INGRam, D. S. \& Robertson, N. F. (1965). Interaction between Phytophthora infestans and tissue cultures of Solanum tuberosum. Journal of General Microbiology 40, 43 I- 437 .

IUPAC-IUB COMMISSION ON BIOCHEMICAL NOMENCLATURE (1972). The nomenclature of multiple forms of enzymes. Recommendations (1971). Biochemical Journal 126, 769-771.

KuBICZ, A. (1973). Acid phosphatase III from potato tubers, molecular weight and subunit structure. Acta biochimica polonica 20, 223-229.

Lowry, O. H., Rosebrough, N. J., Farr, A. L. \& Randall, R. J. (I95I). Protein measurement with the Folin phenol reagent. Journal of Biological Chemistry 193, 265-275.

LuCAs, J. A. (1973). Hydrolases and host-parasite interaction in diseases of the potato. Ph.D. thesis, University of Exeter.

ORNSTEIN, L. (1964). Disc electrophoresis. I. Background and theory. Annals of the New York Academy of Sciences 121, 32I-349.

OUCHTERLONY, Ö. (1953). Antigen antibody reactions in gel. IV. Types of reactions in co-ordinated systems of diffusion. Acta pathologica et microbiologica scandinavica 32, 23I-240.

PITT, D. (1970). Changes in hydrolase activity of Solanum tuber tissues during infection by Phytophthora erythroseptica. Transactions of the British Mycological Society 55, 257-266.

PITt, D. \& CoomBes, C. (1968). The disruption of lysosome-like particles of Solanum tuberosum cells during infection by Phytophthora erythroseptica Pethybr. Journal of General Microbiology 53, 197-204.

PITT, D. \& CoomBes, C. (1969). Release of hydrolytic enzymes from cytoplasmic particles of Solanum tuber tissues during infection by tuber-rotting fungi. Journal of General Microbiology 56, $321-329$.

PITT, D. \& GalPIN, M. (1971). Increase in ribonuclease activity following mechanical damage to leaf and tuber tissues of Solanum tuberosum L. Planta 1or, 317-332.

Rudolph, K. \& StahmanN, M. A. (1966). Multiple hydrolases in bean leaves (Phaseolus vulgaris L.) and the effect of halo blight caused by Pseudomonas phaseolicola (Burkh.) Dowson. Plant Physiology 4r, 389394.

Sako, N. \& StahmanN, M. A. (1972). Multiple molecular forms of enzymes in barley leaves infected with Erysiphe graminis f.sp. hordei. Physiological Plant Pathology 2, 217-226.

Staples, R. C. \& Stahmann, M. A. (1964). Changes in protein and several enzymes in susceptible bean leaves after infection by the bean rust fungus. Phytopathology 54, 760-764.

Uritani, I. (197I). Protein changes in diseased plants. Annual Review of Phytopathology 9, 2 I I-234.

Williams, P. H. \& Staples, R. C. (1964). Acid phosphatase from healthy and rust infected pinto bean leaves. Contributions from the Boyce Thompson Institute for Plant Research 22, 269-282. 